\title{
ACTIVE SEISMOTECTONIC STRUCTURES IN THE AREA OF CHIOS ISLAND, NORTH AEGEAN SEA, REVEALED FROM MICROSEISMICITY AND FAULT PLANE SOLUTIONS
}

\author{
Karakostas, V. G. ${ }^{1}$, Papadimitriou, E. E. ${ }^{1}$, Tranos, M. D. ${ }^{2}$ \\ and Papazachos, C. B. ${ }^{1}$ \\ ${ }^{1}$ Geophysics Department, School of Geology, Aristotle University of Thessaloniki, GR54124, Thessaloniki, \\ Greece,vkarak@geo.auth.gr,ritsa@geo.auth.gr,kpapaza@geo.auth.gr \\ ${ }^{2}$ Geology Department, School of Geology, Aristotle University of Thessaloniki, GR54124, Thessaloniki, \\ Greece,tranos@geo.auth.gr
}

\begin{abstract}
Data from a digital seismological network operating during April-July 2002 were used for the microseismicity study of the area around Chios Island (East Aegean Sea, Greece). Numerous microearthquakes were detected and more than 950 well-located hypocenters were obtained along with 96 reliably determined focal mechanisms. The epicentral distribution and focal mechanisms of several earthquakes revealed that the NE-SW striking dextral strike-slip faults dominate in the study area as is the dominant pattern in North Aegean Sea. An earthquake swarm near Psara Island and a cluster offshore the west coast of Chios Island are associated with NW-SE trending left-lateral strike-slip faults, orthogonal to the dextral ones. Near the west coast of the Island the microseismicity evidences that oblique faulting dominates, whereas onshore and offshore the North Chios Island, clusters of events manifest the activation of either $E-W$ or $N-S$ striking normal faults. This complex deformation pattern is the manifestation of the dextral strike-slip faulting termination against conjugate sinistral ones, the transition from strike-slip to normal through the oblique faulting, as well as the activation of biaxial normal faulting in places.
\end{abstract}

Key words: conjugate strike-slip and normal faults, transition zone, Chios Island, North Aegean.

\section{Introduction}

The study area occupies the eastern central part of the Aegean microplate (Fig. 1) a highly deformed extensional back-arc area. The subduction of the eastern Mediterranean oceanic plate under the Aegean microplate (Papazachos and Comninakis, 1970, 1971) and the westwards motion of the Anatolian microplate along the North Anatolian fault (McKenzie, 1970, 1972, 1978) condition the deformation pattern in this area. The motion of the Anatolian microplate is transferred in the Aegean area as a simple translation, taking place along the central and southern part of the coasts of Turkey and the neighbouring Greek islands. The Aegean moves almost uniformly in a SSW direction ( 200$220^{\circ}$ ) with an average velocity of $\sim 30 \mathrm{~mm} / \mathrm{yr}$, which increases from $25 \mathrm{~mm} / \mathrm{yr}$ in the central and southern part of the western coast of Turkey to $30-35 \mathrm{~mm} / \mathrm{yr}$ near the south western part of the Hellenic arc (Papazachos, 1999), with the significant increase being due to the strong $\mathrm{N}-\mathrm{S}$ extension in the Aegean and western Turkey (McClusky et al., 2000). As a result of these motions, the northern 


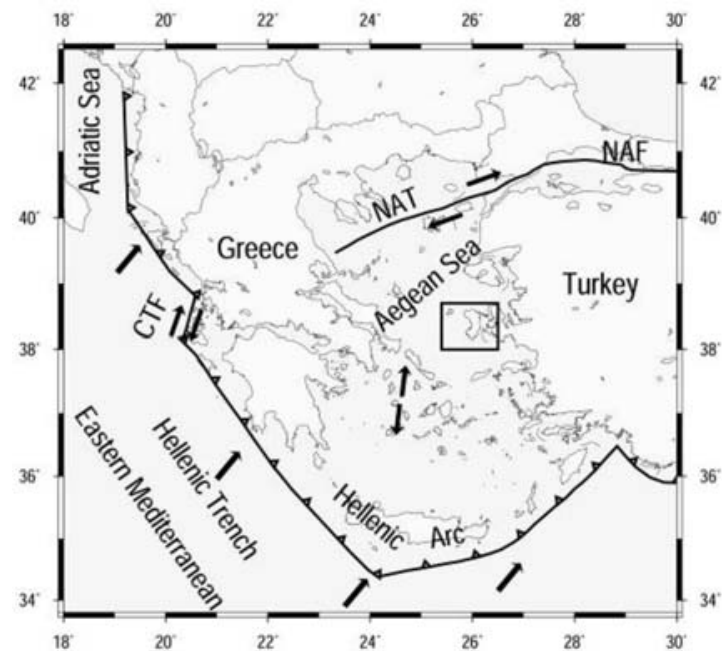

Fig. 1: Main seismotectonic properties of the Aegean and surrounding regions. The study area is denoted by a rectangle.

Aegean is dominated by dextral strike-slip faulting of northeasterly strike, co-existing with normal faulting. Both faulting types are consistent with several fault-plane solutions of recent strong earthquakes (Papazachos et al., 1998) as well as neotectonic observations (Tranos, 2009).

The structure of the area east of Chios Island was investigated by seismic reflection exploration evidencing that the active deformation of both onshore and offshore western Turkey is dominated by crustal extension, whereas strike-slip was evidenced too. The latter is considered to be of greater importance than previously thought (Ocakoğlu et al., 2004). Approximately E-W trending grabens and their basin-bounding active normal faults are the most prominent neotectonic features of this part of western Turkey that is currently experiencing an approximately N-S continental extension at a rate of 30-40 mm·year-1 (Bozkurt, 2001), and is no faster than $\sim 0.5 \mathrm{~mm} \cdot \mathrm{year}^{-1}$ across any individual active normal fault (Westaway, 1994). This extension is related to the spreading and thinning of the crust immediately after the cessation of the Palaeogene shortening (Seyitoğlu and Scott, 1996).

The intense seismic activity in the study area is substantiated by numerous historical earthquakes, with the 1881 (6.5) being the most murderous earthquake in the Greek territory (Papazachos and Papazachou, 2003). During the instrumental period, Chios Island has been struck twice and close in time, in 1941 (M6.0) and 1949 (M6.7). The 1881 and 1949 earthquakes, the stronger more recent events in the study area, ruptured the South Chios and North Chios normal faults, respectively (Papazachos et al., 2001), and caused tsunamis that affected the coasts of Chios Island and Cesme (Altinok et al., 2005).

Microearthquake activity and its relation with the faulting pattern in the study area were not studied up to now. Accurate earthquake location was difficult to be achieved when using teleseismic records, since uncertainties in the structure of the crust and upper mantle can result in errors in earthquake locations of a few tens of kilometres if local or close regional seismological stations are absent. Such errors prevent precise correlations of seismicity with active faults. The purpose of the present study is the exploitation of data collected by a temporary network of nine digital seismological stations that were installed and operated for three months on Chios and neighbouring islands. Their hypocenters, located as much accurately as possible, and fault plane solutions determination, contribute to investigate the local seismic activity and fault kinematics. Even though microseismicity is not completely representative of the properties of the major faults associated with strong earthquake occurrence, it may provide valuable information for defining the seismotectonic 


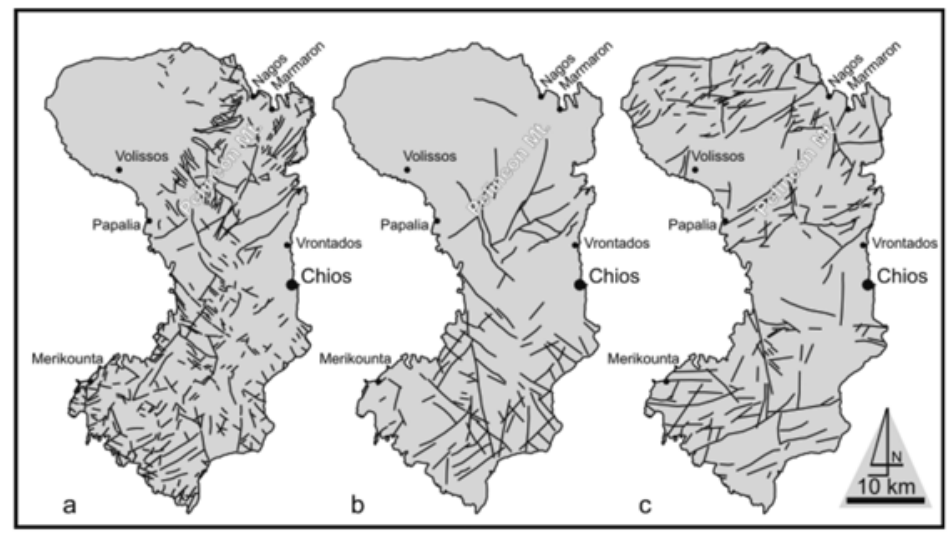

Fig. 2: Simplified structural map of Chios Island showing the fault pattern according to (a) the geological map at scale 1:50.000 (Bescenecker et al., 1971), (b) the geological map presented by Zanchi et al. (2003), and (c) our interpretation of the satellite imagery.

properties of an investigated area.

\section{Geology of Chios Island}

The Island of Chios represents the most proximal to the Anatolian microplate part of the Aegean microplate. It has the shape of upright bin with the central northern parts to form a mountain terrain (Pelineon Mt.) striking NNE-SSW (Fig. 2). The island consists of pre-alpine and alpine rocks that grouped into two units (Zanchi et al., 2003): The Lower Unit (autochthonous of Besenecker et al., 1968) includes siliclastic turbidites and embedded olistoliths of Silurian to Carboniferous rocks and a Mesozoic carbonate succession, and the Upper Unit (allocthonous, Besenecker et al., 1968), which occurs in isolated klippen, displaced by faults related to the Neogene Aegean extension. It includes Upper Carboniferous turbidites, Lower Permian sandy to marly carbonates and Middle Permian shallow-water limestones, overlain by red siltstones and Jurassic platform carbonates.

Late Tertiary metamorphic collapse of Cordilleran type processes dominated the Cycladic archipelago and caused a major shallow-dipping ductile shear zone at the deeper levels and low-angle normal faults in its upper levels elongate domes over which a pervasive N-NNE-stretching lineation is warped (Lister et al., 1984). The succeeding neotectonic evolution of the Aegean Sea concerns WNW-ESE steeply dipping normal faults and NE-SW strike-slip faults that form elongate submarine basins (Kilias et al., 1998). To the east of the study area, i.e. the Minor Asia region is dominated by E-W large active faults that bound similarly oriented elongated valleys along which an intense seismic activity is well established (Ocakoglu et al., 2004). This deformation is related to an approximately N-S continental extension at a rate of 30-40 mm·year ${ }^{-1}$ (Bozkurt, 2001).

The geological mapping of the island of Chios (Besenecker et al., 1971) figures out a fault pattern that is mainly dominated by NNE-SSW faults and WNW-ESE to NW-SE along which several geologic formations have been horizontally separated, thus implying the significance of the strikeslip component of displacement. On the other hand, our fault mapping through the Landsat satellite imagery, which was mainly based on the well used morphotectonic criteria associated with faults, suggests that the recently formed fault pattern is mainly dominated by NE-SW and E-W striking faults. More precisely, the mapped NE-SW faults seem to be the major faults of the island that have 

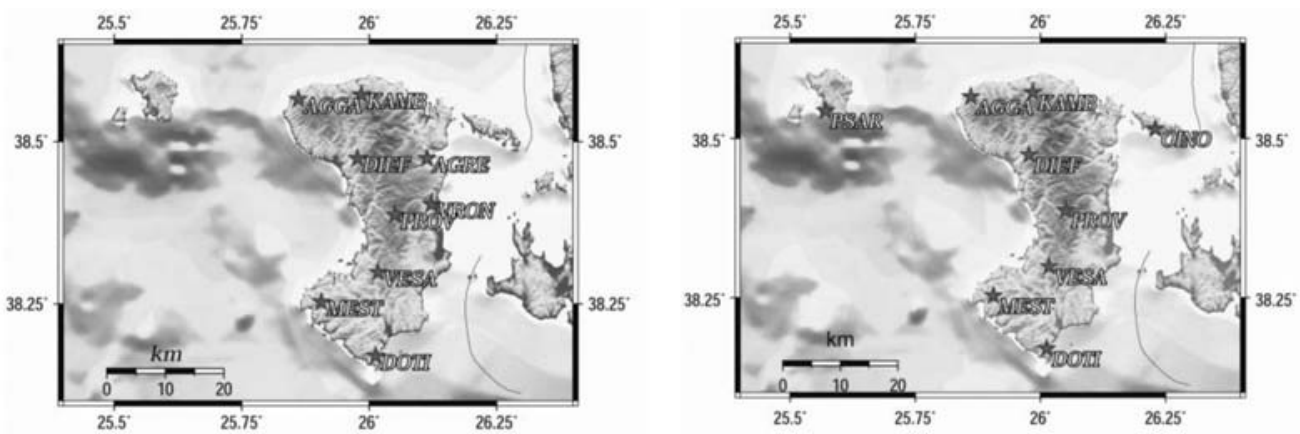

Fig. 3: Locations of the portable seismological stations during the first phase (left part) and the second phase (right part) of the experiment. Stations with code names PSAR and OINO, are positioned on Psara and Oinouses Islands, respectively.

been embraced at parts the previous NNE-SSW fault segments, whereas the E-W faults are of smaller length and are limited by the presence of the NE-SW striking faults (Fig. 2).

One of the most important NE-SW faults hence named the Chios fault is the one running along the SE mountain front of the Pelineon Mt. This fault with a length of at least $7 \mathrm{~km}$ runs close to the Northern suburbs of the Chios city (Vrontados area) and is characterised by recent activity, since it has affected such young deposits as Quaternary. Besides, strike-slip slickenlines have been observed to be overprinted by dip-slip slickenlines along fault surfaces, entailing a normal activation.

\section{Data and procedures}

We analysed the $\mathrm{P}$ and $\mathrm{S}$ wave arrival times and $\mathrm{P}$ wave first motions from a local network that was installed and operated in the area during April-July 2002. The seismic network consisted of nine $3-$ component stations equipped with broad-band sensors, all connected to GPS antenna for timing. The first choice was to place the network on Chios Island (April-June) in order to locate the microseismicity on the Island as much accurately as possible, with station spacing about $10 \mathrm{~km}$ (Fig. 3, left). During the second phase of the experiment, two stations were moved to the nearby Oinouses and Psara Islands, the latter being an area with very high seismic activity (Fig. 3, right). The stations operated in continuous mode with a sampling frequency of $125 \mathrm{~Hz}$, allowing the detection and location of 868 events both on land and offshore.

Arrival time data from the detected events were considered, and by the use of a regional velocity model (Panagiotopoulos, 1984), the best located events were selected in a procedure to define a local velocity model. The criteria applied for dataset selection were the minimum phase number to be no less than 10, the distance to the closer station smaller than $20 \mathrm{~km}$ and the "gap" less than $200^{\circ}$. Accurate solutions considered the ones having a root-mean-square residual (rms) less than $0.4 \mathrm{~s}$, a horizontal location and a depth error both less than $5.0 \mathrm{~km}$. In addition to these criteria, the most important one was the solution stability, i.e., the solution being immutable independently of the input crustal model or the initial focal depth. Thus, 43 events were selected and used to construct travel time curves, and after repetitive iterations a local velocity model was obtained $\left(\mathrm{v}_{1}=5.6 \mathrm{~km} \cdot \mathrm{sec}^{-1}, \mathrm{~d}_{1}=1.3 \mathrm{~km}, \mathrm{v}_{2}=5.94\right.$ $\mathrm{km} \cdot \mathrm{sec}^{-1}, \mathrm{~d}_{2}=5.3 \mathrm{~km}, \mathrm{v}_{3}=6.34 \mathrm{~km} \cdot \mathrm{sec}^{-1}, \mathrm{~d}_{3}=\infty$ ) and a best $\mathrm{v}_{\mathrm{p}} / \mathrm{v}_{\mathrm{s}}$ ratio equal to 1.756 . For improved hypocenters a set of station delays was used in addition with the one-dimensional velocity model as input to HYPO71 (revised, Lee and Lahr, 1975). In the location procedure, the P- and S- arrivals er- 


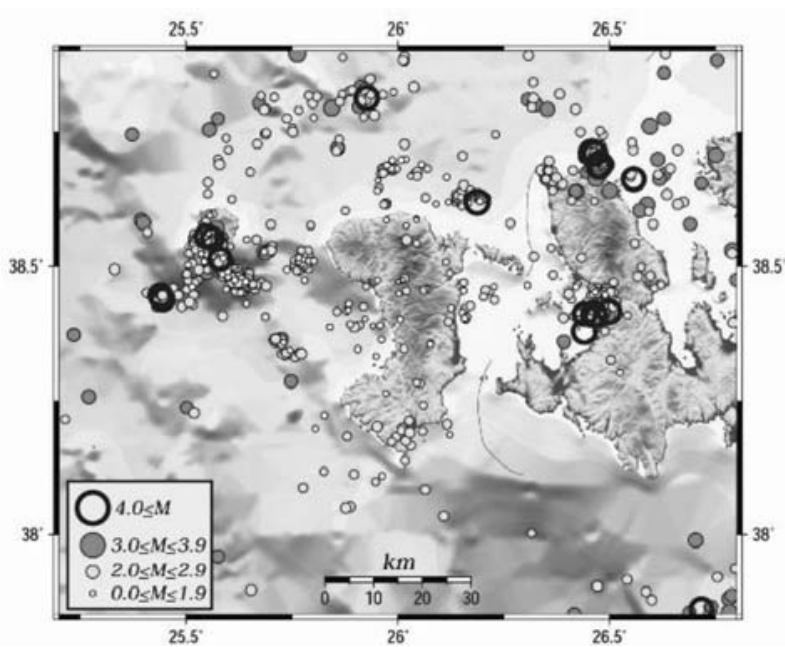

Fig. 4: Spatial distribution of the seismicity recorded by the local network.

rors were taken less than $0.3 \mathrm{~s}$ and $0.7 \mathrm{~s}$, respectively. The final locations had an average root-meansquare residual (rms) of $0.10 \mathrm{~s}$, a mean horizontal error of $1 \mathrm{~km}$, and a mean error in the depth determination equal to $4 \mathrm{~km}$. Depths range between 2-20 km with a remarkable pick on $6-8 \mathrm{~km}$.

Magnitude determination for all the located events was performed from maximum amplitudes (a) and hypocentral distances $(\mathrm{R})$, according to a relation of the form:

where $c_{1}$ was taken equal to $1.0, c_{2}$, which depends on the attenuation, was considered equal to 1.199 , that is a standard value for the territory of Greece and epicentral distances less than $100 \mathrm{~km}$ according to Scordilis (1985). The local magnitudes of 30 events commonly recorded by both the permanent and local seismological networks were used for the calculation of $c_{3}$ in each seismological station of the temporary network. The local magnitudes of the microearthquakes were then transformed into equivalent moment magnitudes based on a relation suggested by Papazachos et al. (1997).

The configuration of the network allowed determining reliable individual microearthquake focal mechanisms. All the single-event, lower-hemisphere focal mechanisms were determined, when more than 5 arrivals were available, using the FPFIT computer program (Reasenberg and Oppenheimer, 1985). In order to avoid misleading determination and to ensure the nodal plane constraints, the station azimuthal coverage as well as the distribution of the compressions and dilatations, were taken into account. The above criteria deterred the focal mechanisms determination of all the recorded events, but the ones located inside the network. A total of 96 mechanisms were computed with a gap smaller than $180^{\circ}$ sampling a minimum of three quadrants. Most of the reliable solutions in the study area exhibit either strike-slip or normal faulting.

\section{Results}

\subsection{Spatial distribution of the seismicity}

The epicentral distribution of the located events is shown in Figure 4, where four different symbols were used to denote four different magnitude ranges. A complex spatial distribution appears with spa- 

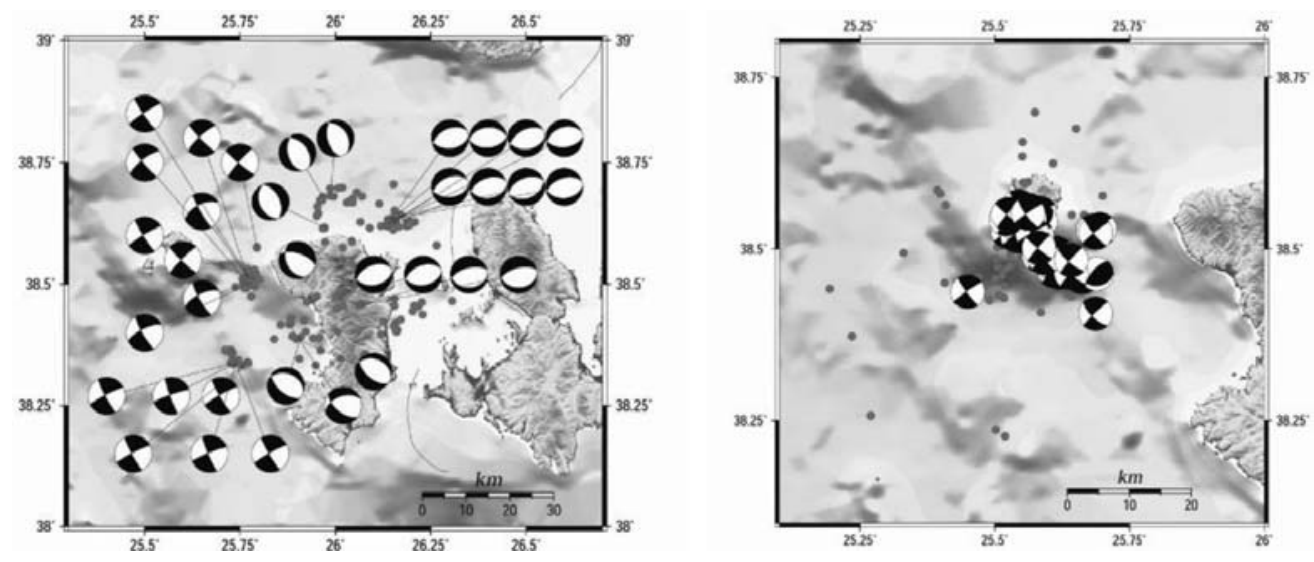

Fig. 5: Fault plane solutions of the 96 events around Chios (left) and close to Psara (right) Islands.

tially distinct clusters, evidencing the existence of a diverse faulting pattern. The most dense cluster is located near Psara Island, where two groups were observed, the larger one striking NNW-SSE and the smaller one striking NNE-SSW. Minor clusters of smaller magnitude events are also observed in the sea area between Psara and Chios Islands, which in some cases define small active structures. The onshore seismicity is weak $(\mathrm{M} \leq 3.0)$, whereas in the northern sea area an offshore cluster is observed with an event of $\mathrm{M}=4.3$. The seismic activity is more intense in the Erithraea peninsula, along the western coast of Asia Minor, with several events of $M \geq 4.0$. A tight cluster of less than $10 \mathrm{~km}$ radius was formed near the city of Tçesme, and one more adjacent to the east coastline of Erithraea Peninsula that continues to the east up to the Smyrne gulf.

It is worth to note here the lack of seismicity in the offshore area to the south of Erithraea peninsula up to Chios Island. The elongated dimension of this area is almost $30 \mathrm{~km}$ and coincides with the meizoseismal area of the destructive 1881 earthquake with $\mathrm{M}=6.5$ (Papazachos and Papazachou, 2003). This presents evidence for seismic quiescence prevailing on the associated south Chios fault even in microearthquake activity.

\subsection{Focal mechanisms of the earthquakes}

The most reliable fault plane solutions determined from first-motion polarities for 96 events are shown in Fig. 5. Nearly all the focal mechanisms close to Psara Island and the sea area between Psara and Chios Islands show strike-slip faulting, whereas the focal mechanisms offshore and onshore Chios show transtensional or normal faulting. Nearby located events exhibit similarities in their fault plane solutions, and in particular, the events that seem to be associated with the same active structure. To detect possible spatial changes in the style of faulting we show focal mechanisms grouped by style of faulting and belonging to the same spatial cluster. These mean focal mechanisms are summarized in Table 1 and shown in Fig. 6, along with the orientation of the axis of maximum extension (T-axis), which is prevalent in the study area. Although since the completion of the WWSSN in 1964, no strong events have been recorded in the study area and therefore focal mechanisms are not available, information on predetermined focal mechanisms of two strong earthquakes that occurred in nearby areas is used for comparison with the fault plane solutions determined in this study. 
Table 1. Mean fault plane solutions for the seven clusters.

\begin{tabular}{|c|c|c|c|c|c|c|c|c|c|c|c|c|}
\hline \multirow{2}{*}{ Area } & \multirow{2}{*}{ Lat. } & \multirow{2}{*}{ Long. } & \multicolumn{3}{|c|}{ Plane 1 } & \multicolumn{3}{c|}{ Plane 2 } & \multicolumn{2}{c|}{ P axis } & \multicolumn{2}{|c|}{ T axis } \\
\cline { 5 - 15 } & & & $\boldsymbol{\phi}^{\mathbf{0}}$ & $\boldsymbol{\delta}^{\mathbf{0}}$ & $\boldsymbol{\lambda}^{\mathbf{0}}$ & $\boldsymbol{\phi}^{\mathbf{0}}$ & $\boldsymbol{\delta}^{\mathbf{0}}$ & $\boldsymbol{\lambda}^{\mathbf{0}}$ & $\boldsymbol{\phi}^{\mathbf{0}}$ & $\boldsymbol{\delta}^{\mathbf{0}}$ & $\boldsymbol{\phi}^{\mathbf{0}}$ & $\boldsymbol{\delta}^{\mathbf{0}}$ \\
\hline Area 1 & 38.520 & 25.769 & 234 & 76 & -171 & 142 & 82 & -13 & 52 & 8 & 144 & 14 \\
\hline Area 2 & 38.632 & 25.986 & 162 & 46 & -70 & 315 & 47 & -108 & 225 & 43 & 72 & 44 \\
\hline Area 3 & 38.631 & 26.148 & 85 & 45 & -77 & 249 & 47 & -101 & 159 & 43 & 355 & 45 \\
\hline Area 4 & 38.342 & 25.744 & 153 & 84 & -5 & 244 & 84 & -173 & 154 & 6 & 63 & 6 \\
\hline Area 5 & 38.399 & 25.895 & 277 & 35 & -116 & 129 & 59 & -71 & 39 & 31 & 187 & 55 \\
\hline Area 6 & 38.466 & 26.039 & 84 & 36 & -80 & 254 & 55 & -95 & 164 & 35 & 354 & 54 \\
\hline Psara & 38.514 & 25.584 & 141 & 80 & -6 & 232 & 83 & -169 & 142 & 7 & 51 & 10 \\
\hline
\end{tabular}

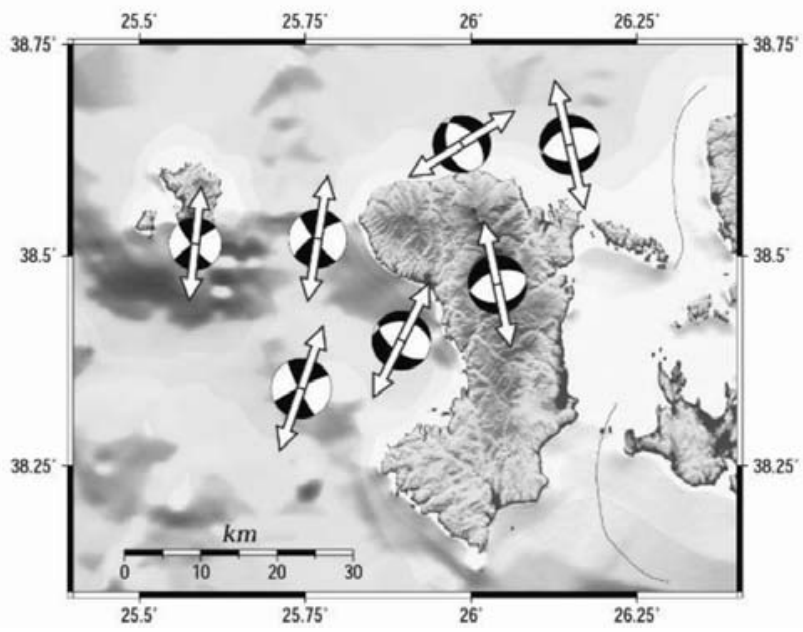

Fig. 6: Composite focal mechanisms corresponding to the seven clusters of microseismicity.

Mechanisms related to small-magnitude earthquakes are not usually associated with the finite slip on major faults and their slip vectors could be associated with the motion of randomly distributed preexisting faults, but $\mathrm{P}$ or $\mathrm{T}$ axes should be oriented as the main stress directions. Therefore, the direction of axis of maximum extension in the present case is a very useful parameter and is shown together with the mean focal mechanisms in Fig. 6.

A cluster of 62 events was located adjacent to the southwestern coast of Psara Island, forming en elongated structure trending NW-SE (Fig. 5, right and mean mechanism in Fig. 6), evidencing that the nodal planes with this strike might be considered as the fault planes and that the sinistral strikeslip motion prevails in this area. Another cluster of 6 events off the southwestern coast of Chios Island seems to be the continuation of the former active structure (Fig. 5, left and mean mechanism in Fig. 6). The strike-slip faulting events forming a cluster off the northwestern coast of Chios Island are distributed in a rather NE-SW lineament suggesting their association with the dextral strikeslip faults prevailing in the North Aegean Sea (Fig. 5, left and mean mechanism in Fig. 6) and in accordance with the 2001, M5 6 event $\left(\right.$ strike $=244^{\circ}$, dip $=79^{\circ}$, rake $\left.=-164^{\circ}\right)$. The coexistence of left- 

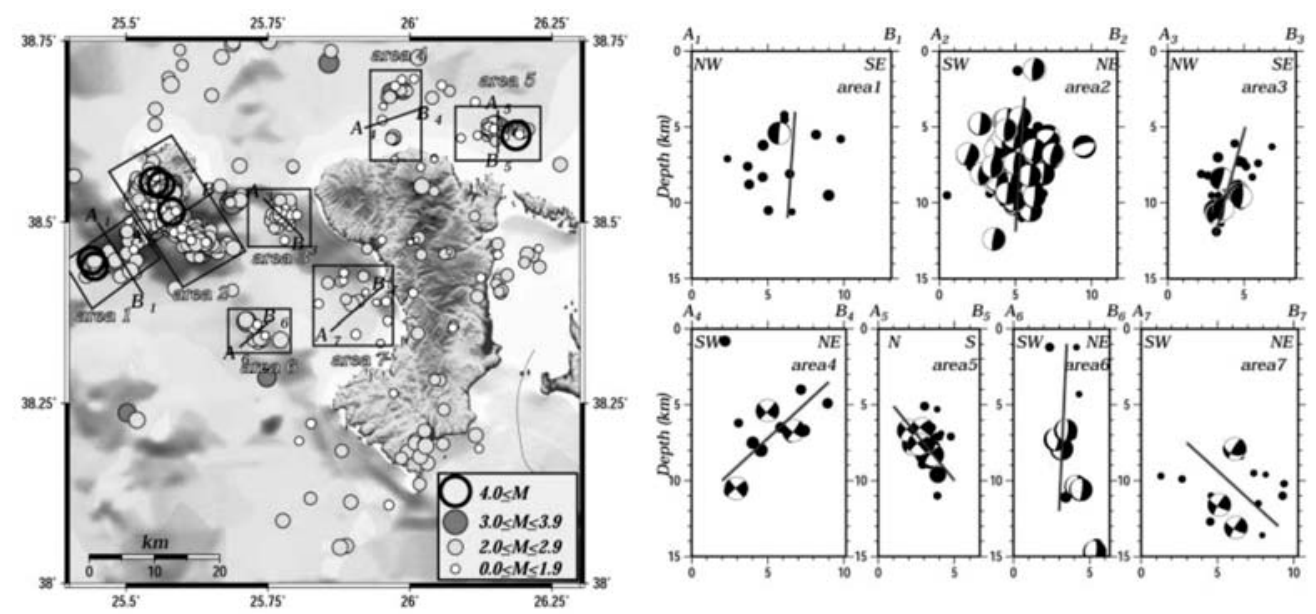

Fig. 7: The seven clusters of the microseismicity circumscribed by rectangles (left part) and the corresponding cross sections (right part).

lateral and right-lateral strike-slip faulting or possibly conjugate faulting has also been observed in the western part of the Aegean Sea, where such activation was observed during the 2001 Skyros Island sequence (Karakostas et al., 2003).

West of Chios Island, the results suggest that oblique extension prevails (Fig. 5, left and mean mechanism in Fig. 6), while the cluster offshore the northern coast exhibits rather E-W extension (Fig. 5, left and mean mechanism in Fig. 6). The orientation of the mean T-axis determined from this cluster is positioned rather perpendicular to the ones determined from the rest clusters, implying biaxial extension. A tectonic association is possible between the normal faulting events located at the northern inland part of Chios (Fig. 5, left and mean mechanism in Fig. 6) with the Vrontados-Karies fault as already found by the geological field observations. In the sea area north of the northeastern coast of Chios the determined 8 fault plane solutions clearly exhibit similar with the previous group normal faulting in almost ENE-WSW trending fault planes (Fig. 5, left and mean mechanism in Fig. 6). This mean fault plane solution is in agreement with the mechanism of the 1969, M5.9 event ( strike $=100^{\circ}, \operatorname{dip}=60^{\circ}$, rake $=-90^{\circ}$ ) that occurred eastwards on Erithraea Peninsula.

In summary, the complex faulting pattern exhibits several distinctive seismotectonic features. First, the evidence of the left-lateral NW-SE trending strike-slip faults that seated orthogonal to the prevalent NE-SW dextral strike-slip faults in North Aegean Sea. Second, the transtensional faulting between strike-slip and normal faulting from west to east. Third, the active two almost parallel normal faulting structures, onshore and offshore Chios Island, in agreement with the stress pattern that holds in western Asia Minor. Fourth, the E-W extension offshore the northern coast of Chios Island that evinces the biaxial extension. Thus, from the above spatial distribution it is reasonable to conclude that west of the Chios Island strike-slip faulting prevails, and going to the east through a transition zone of oblique normal faulting, biaxial extension on almost $\mathrm{E}-\mathrm{W}$ or $\mathrm{N}-\mathrm{S}$ normal faults is emerging.

\subsection{Geometry of the active structures}

In order to investigate further the geometry of the active structures we divided the region into seven rectangles comprising the seismicity clusters, shown in Fig. 7 (left) along with seismicity and the lo- 


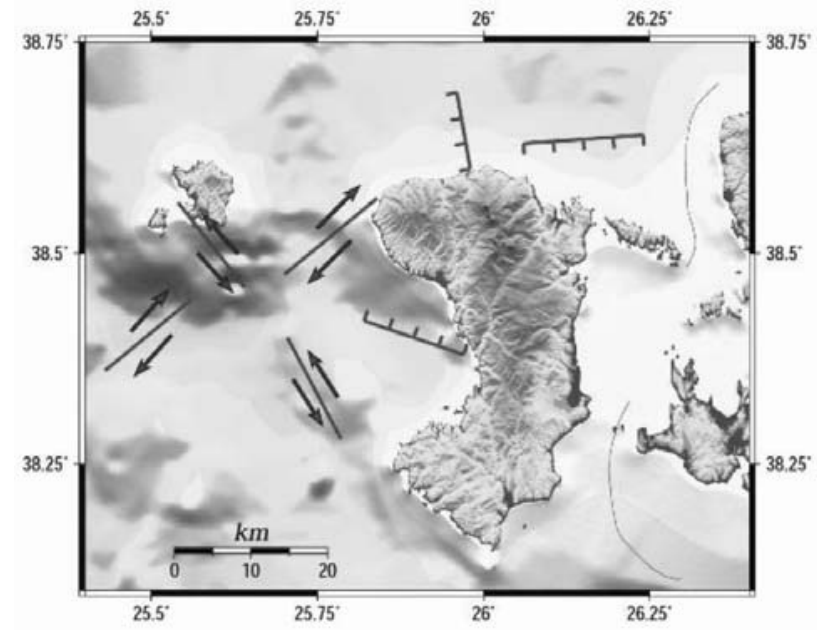

Fig. 8: The identified active structures associated with the analysed microseismicity.

cations of cross sections. The sections, which are perpendicular to the mean trend of the seismicity and are deliberately chosen to be narrow to reveal details, were performed with front projections of the focal mechanisms that were determined in each rectangle (Fig. 7, right). The thickness of the seismogenic layer comes to $15 \mathrm{~km}$, with the vast majority of the hypocenters being between 5 and $10 \mathrm{~km}$ in all sections. The dips of the nodal planes are in good agreement with the mean dips of the clusters defined by the hypocenters alone. A summary of the above analysis is illustrated on the map of Fig. 8 .

\section{Discussion and conclusions}

The purpose of this study is to characterize the active deformation onshore and offshore Chios Island. Numerous geological studies have been carried out in the broader Aegean region as well as in western Turkey, but poor detailed structural analysis has been done for the study area. On the other hand, seismological station coverage form the permanent seismological network was not adequate to permit a detailed seismological investigation. Our results show that a dense seismological network is essential to detect and accurately locate microseismicity and then to image active structures in areas which either were not activated during the instrumental period or the historical record is incomplete. The microseismicity within the study area was lower than the average seismic activity of the broader Aegean region during the local network operation. The largest local events occurred in Psara Island and offshore the northeastern coasts of Chios Island. Microseismicity was completely absent on the south Chios fault where the 1881 event occurred, and hence this area still requires further investigation to reveal this fault configuration.

In addition to the prevailing stress pattern in a certain area, faulting may occur on preexisting zones of weakness and therefore, the data set should contain focal mechanisms of diverse dislocation types. The fault plane solutions determined in the present study exhibit a complex fault pattern including dextral and sinistral strike-slip motion, transtensional as well as biaxial extension. Biaxial extension not only in almost N-S but also in the orthogonal east-west direction has been suggested for western Turkey by Westaway (1994) and Cihan et al. (2003) who thus explained the complex faulting there. In accordance with the findings of the present work are the results derived from the analysis of the seismic activity taking place within the Gulf of Sigarcik, $50 \mathrm{~km}$ southwest of Izmir (Aktar et 
al., 2007), in that the aftershock activity was clustered in two distinct zones, roughly perpendicular to each other. Fault plane solutions of the three major $(M \geq 5.4)$ events of the sequence are consistent with the orientation of both zones, striking NNW-SSE and NE-SW, respectively, which form a conjugate strike slip system. This difference in the orientation of the extension for different sub areas suggests that the study area is affected by internal deformation, which controls the activation of the active structures and their faulting type.

\section{Acknowledgments}

This work was supported by the Ministry of Aegean and Prefecture of Chios. The GMT system (Wessel and Smith, 1998) was used to plot the figures. Department of Geophysics Contribution 752.

\section{References}

Aktar, M., Karabulut, H., Özalaybey, S. and Childs, D., 2007. A conjugate strike -slip fault system within the extensional tectonics of Western Turkey. Geophys. J. Int., 171, 1363-1375.

Altinok, Y., Alpar, B., Özer, N. And Gazioglu, C., 2005. 1881 and 1949 earthquakes at the Chios-Cesme Strait (Aegean Sea) and their relation to tsunamis. Nat. Haz. \& Earth Syst. Sci., 5, 717-725.

Besenecker, H. Durr, S., Herget, G., Jacobshagen, V., Kauffmann, G., Ludtke, G., Roth, W. and Tietze, K., 1968. Geologie von Chios (Agais). Geol. Paleontol., 2, 121-150.

Besenecker, H. Durr, S., Herget, G., Kauffmann, G., Ludtke, G., Roth, W. and Tietze, K., 1971: Chios (2 sheets), Geological map of Greece at scale 1:50000, I. G. S. R., Athens.

Bozkurt, E., 2001. Neotectonics of Turkey - a synthesis. Geodan. Acta, 14, 3-30.

Cihan, M., Saraç, G. and Gökçe, O., 2003. Insights into biaxial extensional tectonics: an example from the Sandikli graben, West Anatolia, Turkey. Geological J., 38, 47-66.

Karakostas, V. G., Papadimitriou, E. E., Karakaisis, G. F., Papazachos, C. B., Scordilis, E. M., Vargemezis, G. and Aidona, E., 2003. The 2001 Skyros, Northern Aegean, Greece, earthquake sequence: off-fault aftershocks, tectonic implications, and seismicity triggering, Geophys. Res. Lett., 10.1029/2002GL015814.

Kilias, A.A., Mountrakis, D. M., Tranos, M. D. and Pavlides, S. B., 1998. The pre-volcanic metamorphic rocks of Santorini Island: Structural evolution and kinematics during the Tertiary (South Aegean, Greece). In: European Laboratory Volcanoes, Proc. $2^{\text {nd }}$ workshop on Europ. Lab. Volcanoes, eds: R. Casale, M. Fytikas, G. Sigvaldasson and G. Vougioukalakis, Europ. Comm., Sci. Res. Develop., 2336.

Lee, W. H. K. and Lahr, J. C., 1975. HYPO71 (revised): A computer program for determining hypocenter, magnitude and first motion pattern of local earthquakes, U. S. G. S. Open File Rep., 75-311.

Lister, G. S., Banga, G. \& Feenstra, A., 1984. Metamorphic core complexes of Cordilleran type in the Cyclades, Aegean Sea, Greece. Geology, 12, 221-5.

McClusky, S., Balassanian, S., Barka, A., Demir, C., Georgiev, I., Hamburger, M., Hurst, K., Kahle, H., Kastens, K., Kekelidze, G., King, R., Kotzev, V., Lenk, O., Mahmoud, S., Mishin, A., Nadariya, M., Ouzounis, A., Paradisis, D., Peter, Y., Prilepi, M., Reilinger, R., Sanli, I., Seeger, H., Tealeb, A., Toksoz, M. N. and Veis, G., 2000. GPS constraints on crustal movements and deformations in the Eastern Mediterranean (1988-1997): Implications for plate dynamics J. Geophys. Res., 105, 5695-5719.

McKenzie, D. P., 1970. The plate tectonics of the Mediterranean region. Nature, 226, 239-243.

McKenzie, D. P., 1972. Active tectonics of the Mediterranean region. Geophys. J. R. astron. Soc., 30, 109-185. 
McKenzie, D. P., 1978. Active tectonics of the Alpine-Himalayan belt: the Aegean Sea and surrounding regions. Geophys. J. R. astron. Soc., 55, 217-254.

Ocakoğlu, N., Demirbağ, E. and Kuşçu, I., 2004. Neotectonic structures in the area offshore of Alaçati, Doğanbey and Kuşadasi (western Turkey): evidence of strike-slip faulting in the Aegean extensional province. Tectonophysics, 391, 67-83.

Panagiotopoulos, D. G., 1984. Travel time curves and crustal structure in the southern Balkan region. Ph. D. Thesis, Univ. of Thessaloniki, pp. 173 (in Greek).

Papazachos, B. C. and Comninakis, P. E., 1970. Geophysical features of the Greek island arc and eastern Mediterranean ridge. Com. Ren. Des Sceances de la Conference Reunie a Madrid, 1969, 16, 74-75.

Papazachos, B. C. and Comninakis, P. E., 1971. Geophysical and tectonic features of the Aegean arc. J. Geophys. Res., 76, 8517-8533.

Papazachos, B. C. and Papazachou, C., 2003. The earthquakes of Greece. Ziti Publ., Thessaloniki, Greece, $317 \mathrm{pp}$.

Papazachos, B. C., Kiratzi, A. A. and Karakostas, V. G., 1997. Toward a homogeneous moment magnitude determination in Greece and surrounding area. Bull. Seism. Soc. Am., 87, 474-483.

Papazachos, B. C., Papadimitriou, E. E., Kiratzi, A. A., Papazachos, C. B. and Louvari, E. K., 1998. Fault plane solutions in the Aegean Sea and the surrounding area and their tectonic implications. Boll. Geof. Teor. Appl., 39, 199-218.

Papazachos, B. C., Mountrakis, D. M., Papazachos, C. B., Tranos, M. D., Karakaisis, G. F., and Savvaidis, A. S., 2001. The faults that caused the known strong earthquakes in Greece and surrounding areas during $5^{\text {th }}$ century B. C. up to present, $2^{\text {nd }}$ Conf. Earthq. Engin. and Engin. Seism., 2-30 September 2001, Thessaloniki, 1, 17-26.

Papazachos, C. B., 1999. Seismological and GPS evidence for the Aegean-Anatolia interaction. Geophys. Res. Lett., 26, 2653-2656.

Reasenberg, P. and Oppenheimer, D., 1985. FPFIT, FPPLOT and FPPAGE: Fortran programs for calculating and displaying earthquake fault plane solutions. U. S. G. S., Open-File Rep., 95-515, 24pp.

Scordilis, E. M., 1985. Microseismicity study of the Servomacedonian zone and the surrounding area. Ph. D. Thesis, Thessaloniki Univ., Greece, pp. 250 (in Greek with English abstract).

Seyitoğlu, G. and Scott, B. C., 1996. The cause of N-S extensional tectonics in western Turkey: tectonic escape vs back-arc spreading vs orogenic collapse. J. Geodynamics, 22, 145-153, 1996.

Tranos, M. D., 2009. Faulting of Lemnos Island: a mirror of faulting of the North Aegean Trough (Northern Greece). Tectonophysics, 467, 72-88.

Wessel, P. and Smith, W. H. F., 1998. New improved version of the Generic Mapping Tools released. EOS, Trans. Am. Geophys. U., 79, 579.

Westaway, R., 1994. Evidence for dynamic coupling of surface processes with isostatic compensation in the lower crust during active extension of western Turkey. J. Geophys. Res., 99, 20,203-20,233.

Zanchi, A., Garzanti, E., Larghi, C., Angiolini, L. and Gaetani, M., 2003. The Variscan orogeny in Chios (Greece): Carboniferous accretion along a Palaeotethyan active margin. Terra Nova, 15, 213-223. 